\title{
Thoughts on Cultural Exchange Between Heihe City and Blagoveshchensk City*
}

\author{
Chuanhuai Peng \\ Russian Studies \\ Heihe University \\ Heihe, China 164300
}

\author{
Chuanyong Peng \\ Russian Studies \\ Heihe University \\ Heihe, China 164300
}

\begin{abstract}
In recent years, Heihe City has taken advantage of geographical relationship and European-Asian cultural integration to build a unique platform, and has obtained fruitful achievement in the official cultural exchanges, folk cultural exchanges and educational exchanges with Blagoveshchensk city. It has deepened and broadened the comprehensive strategic partnership of cooperation between China and Russia. It has raised the cultural exchange with Blagoveshchensk city to a new level. At the same time, there are still some urgent problems to be solved in the cultural exchange between Heihe City and Blagoveshchensk. Solving these problems is the key to deepen the cultural exchanges with Blagoveshchensk city and truly establish the status of "bridgehead" of Blagoveshchensk city in regional cultural exchanges.
\end{abstract}

Keywords-Heihe city; Blagoveshchensk city; cultural exchange

\section{INTRODUCTION}

Sino-Russian cultural exchanges are the premise and foundation for the exchanges in the fields such as SinoRussian politics, economy and education. It is an important way for Chinese and Russian cultures to understand each other, and learn from each other and seek common development. Strengthening Sino-Russian cultural exchanges has great practical significance. First, it is conducive to further deepening the mutual understanding and traditional friendship between the Chinese and the Russian. It is conducive to the elimination of political differences and doubts. Second, it is conducive to consolidating SinoRussian strategic partnership. It is of great significance to safeguard common interests and promote common development. Third, it is conducive to the promotion of bilateral economic and trade, scientific and technological cooperation, complementary advantages, mutual benefit and win-win situation. Fourth, it is conducive to strengthening China's cultural soft power and expanding the international influence of Chinese culture. Since the beginning of the 21st century, especially after China and Russia have been cooperating with each other to carry out the international cooperation year, the pace of cultural exchanges between

*Fund Project: It is the phased objectives of the Philosophy and Social Science Research Project of Heilongjiang Province in 2018-"Research on the Status quo and Function of Sino-Russian Humanities Exchange in Heilongjiang Basin" (18GJE484).
China and Russia has accelerated. Under the background of the rapid development of Sino-Russian cultural exchanges, the cultural exchanges with Russia in Heilongjiang Province, an important province adjacent to Russia, have also entered the fast lane. There are multi-field, multi-faceted and deeplevel cultural exchanges carried out between Heihe city and Blagoveshchensk city. For example, they would participate in the performances and ice-snow festivals held by the other party, dispatch cultural exchanges to experience each other's culture and charm, and seek the higher education cooperation, etc. The cultural exchange between Heihe city and Blagoveshchensk city is an important work of Heilongjiang's foreign cultural exchanges and occupies an irreplaceable position. From 2010 to 2018 , Heilongjiang province held a large-scale Sino-Russian culture exhibition in Heihe city for nine consecutive times, which promoted the cultural exchange work and local economic and cultural development of Heihe city. These are all benefited from the unique geographical advantages of Heihe city and the attention of the government.

The achievements of the cultural exchanges between Heihe city and Blagoveshchensk city are evident in the province and have had certain impact at the national level. Therefore, it is necessary to conduct research on the cultura exchange work between Heihe city and Blagoveshchensk city, and summarize its experience. The purpose of the research is to summarize the achievements and experience of the exchange between Heihe city and Blagoveshchensk city. Secondly, it is to promote the experience. At the same time, the study and summary of the experience of cultural exchange between Heihe city and Blagoveshchensk city will also greatly promote the cultural exchanges between Russia and Heilongjiang Province. There are many problems that restrict development in the cultural exchanges between Heihe city and Blagoveshchensk city. There are also some problems in the cultural exchanges between Russia and Heilongjiang province. Studying these problems and seeking solutions can make the cultural exchange work between Heihe city and Blagoveshchensk city operate orderly, and enhance the soft power of Heihe culture. And then, it will establish the status of "bridgehead" of Heilongjiang Province and even the whole country in the exchanges with Russia. It has great social impact and significant practical significance. 
Therefore, based on the actual situation of Heihe city, we try to propose countermeasures on the status quo, problems and how to speed up the cultural exchange between Heihe city and Blagoveshchensk city. That will be helpful for further carrying out cultural exchanges between Heihe city and Blagoveshchensk city, and truly establishing the status of "bridgehead" of regional cultural exchanges with Russia.

\section{ThE STATUS QUO OF CUltural EXCHANGES}

\section{BETWEEN HEIHE CITY AND BLAGOVESHCHENSK CITY}

\section{A. Achieving the Normalization and Scale of Official Cultural Exchanges}

The "Sino-Russian Cultural Exhibition" is a foreign cultural innovation project approved and supported by the Chinese Ministry of Culture and the Heilongjiang Provincial Government. It is a regional, large-scale, comprehensive cultural trade fair and cultural exchange between China and Russia. It is an active exploration and practice to further expand the cultural trade and cultural exchange channels between Heilongjiang province and Russia. The SinoRussian culture exhibition was born in 2010 and is held every year in Heihe city. Heihe city firmly grasped the opportunity and re-thought the new strategy of cultural exchanges with Russia by taking advantage of the unique geographical relationship and cultural advantages of Eurasian culture integration. In 2011, the Cultural Affairs Bureau of Heihe City held a working meeting with the Ministry of Culture of Blagoveshchensk, Russia, realizing the first work docking of cultural exchanges and cooperation between the two parties. And they reached a consensus on establishing regular cooperation and exchange mechanisms and updating cooperation methods. Therefore, the Heihe official exchange with Russian culture has transformed from the temporary and periodic to the current normalization and standardization.

\section{B. Folk Cultural Exchanges with Russia Have Achieved Leap-forward Development}

In the cultural exchanges with Blagoveshchensk city for many years, Heihe city has always adopted the official exchanges, neglecting or paying less attention to folk cultural exchanges. However, in practice, the role of nongovernmental exchanges in the cultural exchanges with Russia has become increasingly prominent. In recent years, the Heihe Municipal Government has gradually realized the importance of folk cultural exchanges with Russia. In the year of 2011, with the support of the municipal government, revolving around the Russian art market, relying on the exhibition hall to promote the exhibition, using the Heihe Museum to build the Sino-Russian Art Exhibition Hall, Heihe city established the first Sino-Russian art exhibition company in China, Heihe Longjiang International Cultural Exhibition Co., Ltd. This company vigorously carries out the exchange, research, collection, display, education, marketing and auction of Sino-Russian culture and art. The establishment of the company marks that the folk in Heihe city has rid themselves of individual combat operations in the cultural exchanges with Blagoveshchensk city, achieving a leap-forward upgrade, and forming a pattern of equal development between official cultural exchanges and the folk exchanges with Blagoveshchensk city.

\section{Forming a New Pattern of Educational Exchanges and Cooperation with Russia}

Education is an important field of cultural exchange between Heihe city and Blagoveshchensk city. As early as the end of the 1980s, the educational institutions in Heihe city reached a cooperation agreement with the educational institutions in Blagoveshchensk city. Based on the concept of sharing educational resources and complementing each other's advantages, Heihe City has identified the combination and breakthrough of bilateral education and realized allround, wide-area and deep-level exchanges and cooperation from higher education to early childhood education. A new pattern of educational exchanges and cooperation between Heihe city and Blagoveshchensk city has formed. Among them, Heihe College, as the representative, has played a leading role in the exchange and cooperation of higher education with Blagoveshchenk city. In recent years, Heihe College has adhered to the road of cooperating with Blagoveshchensk in running a school. In addition to sending students to universities in Blagoveshchensk city, hiring experts, and jointly training undergraduate students and the masters, they also jointly establish research bases, compile teaching materials, construct joint research teams, joint academic journals, joint academic seminars, etc. They also build a Sino-Russian scientific research cooperation platform, leading international academic exchanges. In 2007, with the approval of the Ministry of Education, Heihe College and Blagoveshchensk National Normal University jointly established the third Confucius Institute in Russia to promote the spread of Chinese culture. In June 2009, the National Sino-Russian University Student Exchange Base and the Russian Center were approved by the Ministry of Education to settle in Heihe College. In September of the same year, Heihe College and the China International Student Service Center jointly established the first training base for studying in Russia. Relying on the international exchange platform, Heihe College actively organized the "National Exchange Cadres Training", "Sino-Russian College Student Art Festival" and "Sino-Russian Education Friendship Week", "Russian Language and Culture Week", "Heihe College • Far East University Athletics Games", "Sino-Russian University Science and Technology Innovation Competition", "Hand in Hand to Share Sunshine" International Youth Association, "One Blue Sky and One Dream" Sino-Russian Youth Fellowship Activity and other more than 100 high-level and large-scale activities during the "National Year" and "Language Year" activities. It has established the status of "bridgehead" and "junction station" for "educational exchanges".

\section{PRoblems IN THE CUltural EXChANGE BetweEN HEIHE CITY AND BLAGOVESHCHENSK CITY}

The cultural exchanges between Heihe city and Blagoveshchensk city have achieved remarkable results in 
recent years and formed a benign development trend. However, there are still obvious problems to be solved.

\section{A. There Is an Imbalance in Cultural Exchanges}

In recent years, the official cultural exchanges between Heihe City and Blagoveshchensk City have achieved normalization and scale, and the folk cultural exchanges with Russia have achieved leap-forward development, forming a situation in which the government and the people have cultural exchanges with Russia. However, the folk cultural exchanges and official exchanges between Heihe City and Blagoveshchensk city only coexist, and they are not equal. There is an obvious imbalance between the folk cultural exchanges and official exchanges with Russia. First, the official guidance and promotion for the folk cultural exchanges with Russia is not enough. In recent years, the government has attached great importance to cultural exchanges with Russia and has held many large-scale SinoRussian cultural exchange activities, such as the "SinoRussian Cultural Exhibition", the "Sino-Russian Education Friendship Week", and the "Russian Language and Culture Week". It has played the better demonstration role. However, the official guidance and the promotion for nongovernmental organizations participating in the cultural exchanges with Russia are not enough. The activities basically stayed at the official level, and the participation of non-governmental organizations was not wide enough, which affected the export of folk culture to Russia. Second, there are certain problems in the non-governmental organization. The non-governmental organization lacks theoretical intervention in Russian cultural exchanges. It is urgent to systematically summarize and theoretically improve its experience and lessons. The non-governmental organizations pursue economic benefits, and there is disorderly competition. The non-governmental organization personnel flow frequently and the talents are not enough, lacking of stability in the cultural exchanges with Russia. The degree of intensiveness of folk cultural exchanges with Russia is still relatively low, and the level of nongovernmental integration of Russian cultural exchanges is not high.

\section{B. The Breadth and Depth of Cultural Exchanges Need to Be Improved}

In recent years, the cultural exchange between Heihe city and Blagoveshchensk city has made great progress. It has made certain contributions to the development of foreign regional culture. However, it is not difficult to find out the breadth and depth of cultural exchanges between Heihe city and Blagoveshchensk city need to be improved. In terms of the breadth, on the one hand, cultural exchange activities between Heihe city and Blagoveshchensk city are mostly concentrated in Heihe city. There is few cultural exchange activities with Russia carried out in other urban counties, Even if there are some activities, the level of activity is not high, the scale is small, and the impact is not far-reaching. On the other hand, the content of cultural exchanges between Heihe city and Blagoveshchensk city needs to be broadened. At present, the cultural exchanges between Heihe city and Blagoveshchensk city have achieved certain results in the fields of music, sports, art and education. However, the two sides still have a lot of room for improvement in book exchange and inter-library exchanges. There is no substantive cooperation. In terms of the depth, there is a lack of theoretical support for cultural exchanges between Heihe city and Blagoveshchensk city. On the one hand, in recent years, Heihe city has held large-scale cultural exchange activities with Russia, such as the Sino-Russian cultural exhibition of Heilongjiang province. The event was hosted by the Ministry of Culture, and the Cultural Department of Heilongjiang Province. It is a national-level, large-scale cultural exchange activity with Russia. However, there is no cultural forum in the exchange activities, and there is no theoretical guidance on communication activities. On the other hand, the proportion of cultural trade between Heihe city and Blagoveshchensk city is still insufficient. It should improve the ability to promote cultural enterprises and cultural products to go out. Therefore, to innovate and broaden the methods and channels for cultural "going out" requires us to conduct key research.

\section{SugGestions FOR SPEEDING UP THE CUlturaL} EXCHANGE BETWEEN HEIHE CITY AND BLAGOVESHCHENSK CITY

In order to speed up the cultural exchanges work between Heilongjiang Province and Russia, the cultural exchanges with Russia have always been in a benign development cycle In response to the problems in the cultural exchanges with Russia, the author proposes the following countermeasures.

\section{A. Setting Up the Platform, Strengthening Guidance, and Promoting Cultural Exchanges with Russia}

As mentioned above, the cultural exchanges between Heihe city and Blagoveshchensk city have coexisted. However, they have not been equal. This shows that there is still much room for the improvement in the cultural exchanges between the folk of Heihe city and Russia. Therefore, we must adhere to the principle of coexistence of both official exchanges and non-governmental exchanges, vigorously carry out folk cultural exchanges with Russia, actively support civil society to go out, and continuously expand the trade with Russia. Specifically, the first is to strengthen the official exchanges between Heihe city and Blagoveshchensk city, and provide policy support for cultural exchanges between the two sides. The second is to focus on the guidance and promotion of civil society. That is to say, many non-governmental organizations have participated in the official cultural exchanges with Russia, and non-governmental organization is strictly required by official standards. The third is to strengthen the theoretical involvement in the folk cultural exchanges with Russia, and enhance the intercultural communication ability. The fourth is to enhance the cultural connotation of the cultural exchanges between the folk and Russia, and enrich the content of the cultural exchanges between the folk and Russia. The fifth is to integrate the cultural exchange resources, classify these resources and improve the exchange space. 


\section{B. Strengthening the Cultivation of Compound Russian} Talents and Promoting Cultural Exchanges with Russia

Strengthening the cultivation of compound Russian talents is the need of economic and social development in Heihe city, and is also an inevitable choice to promote cultural exchange between Heihe city and Blagoveshchensk city. Therefore, Heilongjiang province should make full use of the comparative advantages of Russian talents, increase the training of compound Russian talents, and provide talent reserves for Russian cultural exchanges. The first is to give full play to the role of higher education and vocational education in Heihe city in cultivating compound Russian talents, and cultivate compound Russian talents through multiple channels. The second is to improve the curriculum and cultivate practical Russian talents through the Russian+professional training model. The third is to give full play to the favorable conditions for Heihe College to jointly run schools with Russia, dispatch the teachers and students, strengthen mutual communication and exchanges, and feel Russian culture. The fourth is to further broaden students' knowledge and enhance the language communication skills.

\section{CONCLUSION}

With the continuous development of Sino-Russian cultural exchanges, Sino-Russian regional cultural exchanges and cooperation have deepened, deepening and broadening the "Comprehensive Strategic Cooperation Partnership" between China and Russia. Based on this, Heihe city should give full play to the advantages of geography and EuropeanAsian cultural integration, actively build a cultural exchange platform for the exchanges with Blagoveshchensk city, broaden the breadth and depth of cultural exchanges, and form a virtuous circle. That will be helpful for Sino-Russian cultural exchanges.

\section{REFERENCES}

[1] To play a leading role in the cultural exchange with Russia and promote the economic development of Heilongjiang procince (http://www.suifenhe.gov.cn).

[2] Guan Changfu, Peng Chuanyong. The status quo, problems and countermeasures of cultural exchange between Heihe city and Russia [J]. Siberian Studies, 2013. 2.

[3] Chen Benzai. Strengthening cultural exchanges and promoting the all-round development of Sino-Russian relations [J]. Siberian Studies, 2002. 4 .

[4] The unique role and geographical advantage of Heilongiiang province in Sino-Russian cultural exchanges (http://www.noelworld.com/channel/newsinfo/infoid/834.html).

[5] Liu Bo. Strengthening cultural exchanges and cooperation between Heilongjiang province and Russia [J]. Siberian Studies, 2005. 5.

[6] Zheng Yingkui. Sino-Russian Cultural Exchanges and the Prospects of Sino-Russian Relations [J]. Science and Technology Consulting Guidance, 2007.

[7] Kuang Yuxia, Wang Juan. A Brief Discussion on Sino-Russian Cultural Exchange $[\mathrm{J}]$. Journal of Urumqi Vocational University, 2010(1).

[8] Li Yanan. On Humanities Exchanges and Cooperation in the Development Process of Sino-Russian Relations [J]. Northeast Asia Forum, 2011 (6). 